SUMMARY OF THE 1977 JACKSON HOLE ARCHAEOLOGICAL INVESTIGATION

\author{
Gary A. Wright \\ State University of New York \\ Albany, New York
}

Teton Creek-Phillips Pass

During the summer of 1977 six major archaeological projects were conducted in northwestern Wyoming.

Thomas Marceau conducted limited site survey in the southern Tetons from the North Fork of Teton Creek to Phillips Pass. He recorded eight new sites. Marceau also continued test excavations at the Hunt site (48 TE 605) on Fish Creek just north of Wilson. Here, he recovered beaver (Castor canadensis) in association with a hearth. A charcoal sample has been submitted for a $\mathrm{C}-14$ date, but the results have not yet been received. An obsidian flake from an undisturbed context in another test square has a hydration date of 1000 B.C., and projectile points from the surface suggest that up to 6000 years of occupation are represented at the site. Larger excavations are planned for 1978.

Moose Basin-Hominy Peak

Susan Bender continued her investigations of the prehistoric exploitation of high country resources in the northern Tetons. So far we have recorded nearly 50 sites at +8000 feet elevation between Moose Basin and Hominy Peak. Two large sites near Conant Pass were tested and one produced a roasting pit similar in form to those excavated previously on the valley floor. The projectile point chronology indicates at least 6000 years of human occupation of this part of the range.

\title{
Lawrence Site
}

The Lawrence site (48 TE 509) on the drowned delta at the north end of Jackson Lake was above water level due to the drought. Funds received from the Bureau of Reclamation permitted a field party under the direction of Priscilla Mecham to map the site for the first time. It is located on a sand beach and consists of extensive scatters of fire cracked rock, roasting pits, rock platforms probably for fish steaming, and chipping debris. It is the single most important site in Jackson Hole, and projectile points from the site, more than 800 collected by W.C. Slim Lawrence alone, suggest perhaps 10,000 years of occupation. Three fire pits were tested and samples for flotation and charcoal for $\mathrm{C}-14$ dates were removed. 
Archaeological research in Teton County over the past several years has resulted in the recording of 307 prehistoric sites. Grand Teton is about $85 \%$ surveyed, but much of the remainder of the county remains unevaluated. We have $10 \mathrm{C}-14$ dates and 34 obsidian hydration dates which, when coupled with the projectile point sequence, provide evidence of around 10,000 years of prewhite occupation. Current evidence suggests that the intensive Native American exploitation of Jackson Hole ended early in the seventeenth century. In addition, we have C-14 dates from three locations in the area that seem to relate to forest fires of unknown size: (a) ca. A.D. 1425 in Moose Basin, (b) ca. A.D. 1600 at Jenny Lake, and (c) less than 200 years ago near Wilson. We have developed a theoretical model to explain the exploitation of high country resources by populations of hunters and gatherers. It was based upon the scheduling of exploitative activities to coincide with the periodicity of key resources in high mountain ecosystems. This hypothesis is being tested with comparative data from the Pryor Mountains, Montana, and the Zagros-Taurus arc of southwestern Asia. Finally, we have constructed a model for differentiating human migrations from the diffusion of artifact types and styles in the absence of historical records using archaeological data.

Bender, Marceau, and Stuart Reeve are currently preparing doctoral dissertations based on the Jackson Hole data. Wright's book The People of the High Country: Jackson Hole Before the Settlers is now in press.

\section{Snake River-Heart Lake}

Lloyd Williams conducted an archaeological survey of the Snake River from South Entrance to the Heart River and then upstream to Heart Lake. This was the first intensive off-road, back-country survey of cultural resources in Yellowstone National Park. He recorded 12 new sites, but our conclusion is that this subarea of Yellowstone was not heavily used by Native Americans in the prewhite times.

\section{Gardiner High Bridge}

Reeve investigated a site (48 TE 320) at the Gardiner High Bridge near Mammoth Hot Springs in Yellowstone Park. Complete surface collections were made from 220 five meter squares, resulting in about 8000 pieces of chipped stone. About $95 \%$ of the material is obsidian. All surface materials have been classified as to types, and tool clusters and manufacturing areas have been defined. These are now being tested by obsidian hydration dating. Surface points run from Agate Basin-like to the Late Prehistoric Period. Excavations revealed that the site, on the middle terrace of a set of three, was underlain by an old stream channel of the Gardiner. The earliest occupation took place before the channel was filled and a lanceolate point was recovered in the stream bed. A report is now in preparation for the National Park Service.

Yellowstone National Park at present has 247 recorded sites and is only about 15\% surveyed. For the summer of 1977 our plans are to survey 
either the Thorofare or the Bechler River region. Both seem to be part of the adaptive territories exploited by the prehistoric Native Americans who also inhabited Jackson Hole and thus are logical extensions of our field work into the latter area. Currently, surprisingly little is known about Yellowstone Park prior to the early nineteenth century in terms of human utilization; this is in marked contrast to Jackson Hole.

\section{Greater Yellowstone Cooperative Regional Transportation Study}

The final major project for 1977 was an environmental impact statement for the Greater Yellowstone Cooperative Regional Transportation Study. We collected and collated archaeological site data for 15 counties of Idaho, Montana, and Wyoming adjacent to Yellowstone and Grand Teton National Parks for the Department of Transportation. This resulted in site survey forms for +1000 sites exclusive of Yellowstone and Grand Teton Parks. All sites, including those in the parks, have been plotted on U.S.G.S. maps and a 60 page report has been submitted by Wright and Marceau along with F.A. Calabrese and Melodie Tune of the Midwest Archaeological Center, Lincoln, Nebraska.

In addition to the above, several smaller projects were conducted. Marceau photographed and measured many of the prehistoric steatite bowls that have been found in Jackson Hole. With Wright he is preparing a paper combining these data with the examples from Yellowstone Park; unfortunately, we were denied permission to restudy the Yellowstone Park bowls. John Krumdieck continued his work on obsidian hydration dating and, along with David Wachtel, collected obsidian samples from the top of Obsidian Cliff which was the most important obsidian quarry in this area. They also initiated a study of ignimbrite, a welded tuff, which outcrops in the northern Tetons and which was a major raw material source for tools found on sites in that subregion of Jackson Hole. Krumdieck is preparing a paper on charcoal identifications from hearths excavated in Jackson Hole. Reeve was able to monitor plant growth of key species for the third year; these data will be used in his dissertation. Finally, several undergraduate students are now engaged in laboratory analyses of the functions of prehistoric stone tools found on sites in northwestern Wyoming. This has included experimentation such as wood cutting, hide scraping, and so on, and their resultant wear patterns.

Many of the preliminary site reports and associated research will appear in a volume edited by Wright entitled Research Reports on the Prehistory of the Jackson Hole Country. This should go to press by February, 1978.

\section{Acknowledgments}

This research has been supported by several contracts received from the National Park Service, Midwest Archaeological Center, Lincoln, Nebraska, and from the Bureau of Reclamation. We wish to thank both Dr. F.A. Calabrese and Dr. Ward Weakly. We also wish to thank Dr. Kenneth Diem, Director of the Jackson Hole Biological Research Station, for continued use of the facilities at the station. 